\title{
PRESIDEN NON-MUSLIM DALAM KOMUNITAS MASYARAKAT MUSLIM
}

\author{
Mary Silvita \\ UIN Syarif Hidayatullah, Jl. Kertamukti Ciputat Jakarta, \\ marysilvita@gmail.com
}

\begin{abstract}
This paper examines the notion of state and leadership according to the contemporary Islamic thought. To be more precise, the paper asks whether it is possible for a non-Muslim to be the president of the majority Muslim country. To answer this, the paper will dwell into the problem of citizenship both in classical and modern Islamic thought by taking into account the political and social situation that shapes this thought. The paper maintains that many Muslims - both in the past and at the present-fail to offer a proper discourse on statehood and leadership in Islamic perspective. The mainstream discourse on this issue-the paper argues-is that which keeps in a good balance the notion of religiosity and citizenship. The rightwing Muslims will provide a textual understanding of the problem, while the left-wing will otherwise offer a secular interpretation of it. This paper will try to keep the two in a balance, and present a fair understanding of what the Qur'an and the Sunnah say about the problem at hand.
\end{abstract}

Keywords: Non-Muslim leadership, Muslim state, citizen rights, political ijtihad.

\section{Pendahuluan}

Polemik tentang boleh-tidaknya seorang non-Muslim memimpin sebuah negara yang penduduknya mayoritas beragama Islam merupakan konsekuensi logis dari sebuah negara yang lebih memilih menjadi negara "abu-abu" daripada memilih secara tegas apakah ia negara agama atau negara sekuler, meskipun wacana negara agama masih perlu ditinjau ulang relevansinya karena setiap pilihan memiliki konsekuensi logis yang berbeda pula. Hak-hak politik warga negara sangat ditentukan oleh bentuk negara. Sebuah negara Islam di mana konstitusi dan segala bentuk peraturan perundang-undangan harus berdasarkan pada kitab suci tidak mungkin melanggengkan seorang 
non-Muslim menjadi pemimpin negara, sebab pemimpin negara Islam harus orang yang memiliki pemahaman komprehensif mengenai Islam, sehingga mustahil tugas tersebut diemban non-Muslim. Sebaliknya, negara sekuler yang konstitusi dan peraturan perundangundangannya tidak didasarkan pada ajaran agama tidak memberikan prasyarat agama tertentu bagi calon-calon pemimpin.

Dilema inilah yang terjadi di Indonesia di mana secara normatif, konstitusi Indonesia tidak mensyaratkan menjadi Muslim untuk dapat mencalonkan diri menjadi presiden. Namun anggapan umum sepertinya lebih cenderung pada logika proporsionalitas, di mana karena mayoritas penduduk Indonesia adalah Muslim, maka semestinya non-Muslim mustahil terpilih menjadi presiden di Indonesia. Pertanyaannya kemudian, apakah keberagamaan mayoritas lantas menjamin akan ditolaknya kepemimpinan dari minoritas? Untuk hal ini sepertinya kita dapat merujuk beberapa negara di dunia yang kaum minoritasnya sanggup menduduki tampuk kekuasaan.

Sebagian besar negara-negara mayoritas Muslim seperti Tunisia, Aljazair, Mesir, Suriah, Pakistan, Bangladesh, Iran, Yordania, dan Malaysia menetapkan presiden atau kepala negaranya harus beragama Islam. Karenanya, di negara-negara tersebut, non-Muslim tidak berhak menjadi presiden. Hanya sebagian kecil saja di antara negaranegara mayoritas yang berpenduduk Islam, yang di samping memperbolehkan, juga pernah dipimpin oleh presiden non-Muslim. Hingga kini setidaknya ada tiga kepala negara yang dapat dijadikan rujukan, yaitu: Nigeria, Senegal, dan Libanon. Nigeria yang 76 persen penduduknya beragama Islam, saat ini, dipimpin seorang presiden yang beragama Kristen. Sebelumnya negara ini juga dipimpin oleh presiden Kristen bernama Olusegun Obasanjo. Satu hal yang sangat menarik dari Olusegun adalah, sekalipun beragama Kristen, ia berhasil menjadi presiden Nigeria yang mayoritas Muslim itu selama tiga periode, yakni periode 1976-1979, periode 1999-2004, dan 20042007. ${ }^{1}$ Setelah Olusegun Obasanjo, Nigeria kembali dipimpin oleh presiden yang beragama Kristen bernama Goodluck Jonathan pada 2007-2010. Goodluck Jonathan terpilih sebagai presiden Nigeria

${ }^{1}$ John L. Esposito, Islam and Politics, terj. Joesoef Sou'yb (Jakarta: Bulan Bintang, 1990), 132. 
dengan mengalahkan rival terdekatnya, Muhammad Buhari, dalam pemilu 2011 dengan perolehan suara 59,6\%.

Seperti halnya Nigeria, Senegal yang $91 \%$ penduduknya beragama Islam juga pernah dipimpin seorang presiden yang beragama Kristen Katolik, yakni Leopold Sedar Senghor (1980-1988). Yang lebih unik lagi adalah Libanon. Negara Timur Tengah ini yang 75 persen penduduknya beragama Islam, sejak tahun 1943 hingga saat ini, selalu dipimpin seorang presiden yang beragama Kristen. Yang menyebabkan mengapa Libanon selalu dipimpin seorang presiden Kristen adalah karena pada tahun 1943 Libanon menyetujui Pakta Nasional (al-Mîthâq al-Watanî) yang berisi ketetapan presiden Libanon harus dari Kristen Maronite, Perdana Menteri dari Muslim Sunnî, Juru Bicara Parlemen dari Muslim Shî’ah, Menteri Pertahanan dari Muslim Druze, dan Menteri Luar Negeri dari Kristen Ortodok Yunani. Oleh karena Pakta Nasional tersebut masih diberlakukan, maka hingga detik ini yang bisa menjadi presiden Libanon hanyalah seseorang yang beragama Kristen Maronite. ${ }^{3}$

Dalam merespons isu ini para ulama juga berbeda pendapat. Secara umum pendapat mereka dapat dibagi menjadi dua mainstream, yakni antara yang menolak kepemimpinan (presiden) non-Muslim dan yang menerima kepemimpinan (presiden) non-Muslim. Yang termasuk ke dalam kelompok pertama antara lain; Abû Bakr Aḥmad b. 'Alî al-Râzî al-Jașṣâș, al-Alûsî al-Baghdâdî, Ibn 'Arabî, al-Kiyâ alHarâsî, Ibn Kathîr, Muhammad Âli al-Ṣâbûnî, Abû al-Qâsim Jâr alAllâh Mạ̣mûd b. 'Umar al-Zamakhsharî al-Khawârizmî, Âli al-Sâyis, Muhammad Husayn al-Ṭabâtabâ‘̂̂, Muhammad b. Aḥmad al-Qurțubî, Wahbah al-Zuhaylî, Muhammad b. 'Alî b. Muhammad b. 'Abd alAllâh al-Shawkânî al-Ṣan'ânî al-Yamanî, Abû Ja’far Muḥammad b. Jarîr b. Yazîd b. Kathîr b. Ghâlib al-Ṭabarî al-Amûlî, Sayyid Quṭb, Abû al-Ḥasan b. Muhammad b. Habîib al-Mâwardî al-Bashrî, 'Abd alMa'âlî al-Juwaynî, 'Abd al-Wahâb Khallâf, Muhammad Diyâ' al-Dîn al-Raîs, Ḥasan al-Bannâ, Hasan Ismaîl al-Hudaybî, Abû al-A'lâ al-

\footnotetext{
${ }^{2}$ Lauren Ploch, "Nigeria Elections and Issues for Congress", Congressional Research Service (May 17th 2011), dalam http://alpha.digital.library.unt.edu/ark:/67531/ metadc40225/m1/1/high_res_d/RL33964_2011May17.pdf (28 Mei 2012).

3 Mujar Ibnu Syarif, Presiden non-Muslim di Negara Muslim: Tinjanan dari Perspektif Politik Islam dan Relevansinya dalam Konteks Indonesia (Jakarta: Pustaka Sinar Harapan, 2006), 75-76. 
Mawdûdî dan Taqî al-Dîn al-Nabhânî. Sementara yang termasuk dalam kelompok kedua antara lain; Mahmoud Mohammad Thaha, Abdullah Ahmad an-Na'im, Târiq al-Bishrî, Asghar Ali Enginer, Muḥammad Saî̀d al-Ashmâwî, ${ }^{5}$ Râshid al-Ghanûshî, Yûsuf alQarḍ̂âî, dan Târiq Ramaḍân. ${ }^{6}$

Fakta di atas menunjukkan bahwa baik secara normatif maupun empirik umat Islam belum sepenuhnya sepaham mengenai bolehtidaknya seorang non-Muslim dipilih menjadi pemimpin dalam masyarakat Islam. Hal ini didasari oleh perbedaan cara pandang terhadap konsep negara dan warga negara dalam sistem politik Islam. Oleh karena itu, tulisan ini akan dimulai dengan pembahasan tentang konsep warga negara dalam sistem politik Islam, kemudian dielaborasi basis argumentasi yang digunakan oleh setiap kelompok yang kemudian dianalisis kesesuaian argumentasi tersebut dengan kondisi saat ini.

\section{Status Non-Muslim dalam Literatur Islam Klasik}

Dalam tradisi Politik Islam klasik, wilayah negara-negara pada saat itu dibagi menjadi dua, Dâr al-Harb dan Dâr al-Islâm, sekaligus ditetapkan status kewarganegaraan non-Muslim pada tiga bagian, yaitu dhimmî, musta'min dan harbî.

a. Abl al-dhimmî menurut al-Ghazâlî (w. 1111 M) adalah setiap ahli kitab yang telah baligh, berakal, merdeka, laki-laki, mampu berperang, dan membayar jižyah. ${ }^{7}$ Sedangkan Ibn al-Juza’i al-Mâlikî memberikan definisinya sebagai "orang kafir yang merdeka, baligh, laki-laki, menganut agama yang bukan Islam, mampu membayar jizyyah, dan tidak gila." Al-'Unqarî (w. 1383 M) mempertegas pendapat di atas dengan menyimpulkan bahwa abl al-dbimmî adalah orang non-Muslim yang menetap di dâr al-Islâm dengan membayar jisyah. ${ }^{8}$

${ }^{4}$ Ibid., 79.

5 Ibid., 140.

6 Tariq Ramadhan, Radical Reform: Islamic Ethics and Liberation (Oxford: Oxford University Press, 2009), 270.

${ }^{7}$ Abû Hâmid al-Ghazâlî, al-Wajî̀ fî Fiqh al-Imâm al-Shâfîu, Vol. 2 (Mesir: Muhammad Muștafâ, 1318 H), 198.

8 Muhammad b. Ahmad b. al-Juza'i al-Kalabî, al-Qawânûn al-Fiqhîyah fî Talkhîs alMadhhab al-Mâlikîyah (Beirut: Dâr al-Qalam, t.th.), 184. 
b. Musta'min adalah abl al-harb yang masuk wilayah Islam atas dasar perlindungan sementara yang diberikan kepadanya oleh imam (negara). Perbedaan antara mustamin dengan dbimmî adalah perlindungan untuk dhimmî bersifat permanen, sedangkan perlindungan untuk musta'min bersifat sementara.'

c. Abl al-ḥarbî adalah kebalikan dari dhimmî, yaitu non-Muslim yang menyatakan permusuhan terhadap kaum Muslimin dan pemimpin kaum Muslimin—atau tidak meyakini negara Islam, mereka tinggal di wilayah mereka yang disebut dâr al-harb. ${ }^{10}$

Berdasarkan klasifikasi di atas, maka non-Muslim yang diakui Islam sebagai warga negara adalah non-Muslim yang berstatus abl aldbimmah. Sebagaimana kaum Muslimin, abl al-dhimmah dapat memperoleh hak perlindungan dari negara Islam serta mendapatkan "hak istimewa" untuk tidak mengikuti wajib militer, namun abl aldhimmah diperbolehkan untuk berpartisipasi dalam bidang militer jika mereka menghendakinya. Menurut beberapa literatur klasik, terdapat sejumlah perbedaan hak dan kewajiban antara warga abl al-dhimmah dengan kaum Muslimin pada umumnya, di antaranya mereka tidak bisa menduduki posisi-posisi strategis dalam pemerintahan, mereka tidak boleh menjadi pemimpin politik dan anggota majelis permusyawaratan, mereka tidak mempunyai hak suara, serta senantiasa diwajibkan membayar jizyah. ${ }^{11}$ Dalam literatur klasik, mereka juga dilarang untuk membunyikan lonceng gereja, dilarang mendirikan rumah ibadah lebih tinggi dari masjid, dan diwajibkan untuk menggunakan pakaian khusus yang berbeda dengan warga Muslim. $^{12}$

\footnotetext{
${ }^{9}$ Yusuf al-Qaradhawi, Fiqih Jihad: Sebuah Karya Monumental Terlengkap tentang Jihad menurut Al-Qur'an dan Sunnah, terj. Irfan Maulana Hakim (Bandung: Mizan, 2010), 751.

10 Ibid.

${ }^{11}$ Kata jizyah merupakan bentuk kata pecahan dari kata al-jazấ yang berarti suatu imbalan atau balasan. Secara definitif, konsep jizyah adalah sesuatu yang diwajibkan terhadap harta yang dimiliki setiap individu dari golongan abl al-dhimmah (nonMuslim) yang tinggal di dalam kekuasaan Islam dan telah mengikat perjanjian dengan pemerintahan. Besarnya nilai jizyah ditentukan oleh tingkat kemakmuran para wajib jizyah. Dalam definisi lain, konsep jizyah juga ditafsirkan sebagai suatu pajak yang ditentukan atas tiap individu yang secara langsung meminta perlindungan pada hukum negara Islam.

12 Shaykh Muhammad b. Șâlih al-'Uthaymîn, Huqûq Dâ'at ilaybâ al-Fịtrah wa Qarrarahâ al-Sharîah (t.t.: Madâr al-Wațan, 1427 H), 26.
} 


\section{Perspektif Modern tentang Konsep Ahl al-Dhimmah}

Dalam konteks negara bangsa modern yang tidak membedakan warga negara berdasarkan agama, etnis, maupun gender seperti di Indonesia, ${ }^{13}$ konsep abl al-dhimmah tentu mengundang ragam persoalan. W. Montgomery Watt menyebutkan bahwa konsep abl aldhimmah dianggap sebagai cikal bakal munculnya marginalisasi hak-hak non-Muslim. ${ }^{14}$ Kedudukan abl al-dhimmah dari perspektif figh klasik ini jika dinilai dengan sudut pandang kekinian tentu saja akan terkesan diskriminatif. Perbedaan hak dan kewajiban kaum non-Muslim di negara Islam masa lampau jika dibandingkan dengan standar keadilan masa kini pasti akan mengesankan bahwa fiqh kontemporer tidak lagi memenuhi standar keadilan, sebab perbedaan hak dan kewajiban yang melekat pada diri non-Muslim ini secara praktis telah menempatkannya sebagai masyarakat kelas dua.

Dalam hal ini Moosae Ibrahim menyatakan bahwa, meskipun saat ini konsep abl al-dhimmah sudah tidak lagi digunakan oleh Negara Muslim mana pun termasuk Iran dan Mesir, sejumlah pemikir tradisionalis dan revivalis Islam masih melihat bahwa konsep abl aldhimmah masih relevan untuk diaplikasikan di abad modern. Pemikiran semacam inilah yang akhirnya menimbulkan ketakutan tersendiri bagi kalangan non-Muslim, bahwa jika partai-partai Islam berkuasa, maka negara akan berubah menjadi "domain Islam", dan non-Muslim di negara itu akan menikmati status kewarganegaraan kelas dua dengan sebutan abl al-dhimmah. ${ }^{15}$

Padahal jika kita merujuk pada praktik kenegaraan Islam yang dicontohkan oleh Rasulullah maka akan didapati bahwa semangat yang diusung dalam konsep abl al-dhimmah adalah semangat "perlindungan", bukan "penindasan". Dalam beberapa butir Piagam Madinah ditegaskan bahwa orang Yahudi yang tinggal di Madinah termasuk warga negara. Mereka mempunyai hak dan kewajiban seperti kaum Muslimin di setiap wilayahnya. Mereka bebas menjalankan

\footnotetext{
${ }^{13}$ Nurcholish Madjid menyebutkan bahwa sistem politik yang sebaiknya diterapkan di Indonesia adalah sistem yang menguntungkan semua orang, termasuk nonMuslim. Hal ini sejalan dengan watak inklusif Islam. Lihat Nurcholish Madjid, Citacita Politik Islam Era Reformasi (Jakarta: Paramadina, 1999), 52.

14 W. Montgomery Watt, Islamic Political Thought (Edinburgh: Edinburgh University Press, 2003), 51.

15 Ibrahim Moosa, "The Dilemma of Islamic Rights Schemes", The Journal of Law and Religion (2000-2001), dalam http:/ / duke.academia.edu/EbrahimMoosa/Papers/ 219897/The_Dilemma_of_Islamic_Rights_Schemes (5 Desember 2011).
} 
agamanya, demikian dengan kaum Muslim juga bebas menjalankan agamanya. Teks Piagam juga menjelaskan bahwa "unsur regional (Madinah) dan domisili saat berdirinya kedaulatan, itulah yang memberikan hak warga negara untuk non-Muslim dan menjamin mereka mendapatkan persamaan hak dan kewajiban" karena mereka adalah "umat yang satu". 16

Terlepas dari butir-butir Piagam Madinah, penghormatan Nabi Muhammad terhadap hak-hak non-Muslim juga bisa dilihat dalam hadîth fi'lî (perbuatan Nabi) yang menceritakan peristiwa ketika Nabi Muhammad dikunjungi oleh sekelompok pemimpin Nasrani yang berjumlah sekitar 16 orang di saat Nabi tengah melaksanakan salat ashar. Ketika melihat Nabi berada di masjid, mereka memaksa masuk ke dalam masjid. Satu cerita menyebutkan bahwa Nabi menolak untuk menerima mereka masuk ke dalam masjid, akan tetapi hal ini dilakukan karena mereka sedang mengenakan jubah dengan ornamen mewah. Namun, setelah mereka melepaskan jubah mereka baru Nabi mau menerima mereka. Ketika mereka selesai berbicara dengan Nabi dan tiba waktu mereka untuk bersembahyang, Nabi mempersilahkan mereka untuk bersembahyang di masjid sambil berkata, "Ini adalah tempat yang suci untuk memuja Tuhan". ${ }^{17}$ Hadîth sahih lainnya yang diriwayatkan oleh al-Ṭabrânî juga menggambarkan maksud yang sama. Nabi berkata, "Siapa pun yang menyakiti seorang dhimmî maka ia juga telah menyakitiku, dan siapa yang menyakitiku maka ia juga telah menyakiti Allah." Hadith lain yang diriwayatkan oleh al-Khâttib, Nabi berkata "siapa pun yang melukai dbimmî, aku akan menjadikannya musuhku, dan siapa pun yang menjadi musuhku maka akan menjadi musuhku di hari kiamat. ${ }^{18}$ Bahkan lebih tegas dan jelas Nabi mengingatkan mereka yang melakukan perbuatan semena-mena apalagi membunuh terhadap non-Muslim tanpa alasan yang dibenarkan agama dan negara sebagaimana tertera dalam hadîth Nabi:

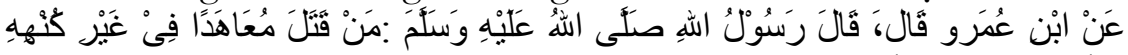

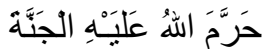

${ }^{16}$ Farid Abdul Khiq, Fikih Politik Islam (Jakarta: Amzah, 2005), 161.

17 Sukron Kamil, "The Progressive Shari $a$ Perspective of non-Muslim Rights", Kultur: The Indonesian Journal for Muslim Cultures, Vol. 4, No. 2 (2009), 138.

18 'Abd al-Raḥmân b. Abû Bakr al-Suyûtî, al-Jâmi al-Saghîr fi Hadîth al-Basbîr alNadhir (t.t.: t.tp., t.th.), 15. 
Barangsiapa yang telah membunuh non-Muslim tanpa alasan yang benar, maka Allah benar-benar melarang baginya masuk surga. ${ }^{19}$

Dalam hal ini Nabi seringkali mengingatkan mereka akan tercelanya perbuatan penganiayaan terhadap non-Muslim sebagaimana dalam hadîth lain disebutkan:
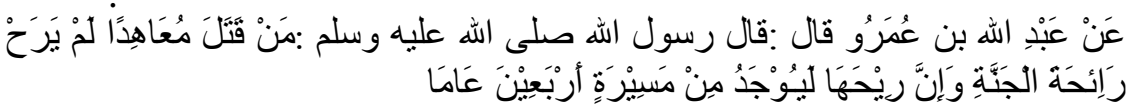

Dari 'Abd al-Allâh b. 'Umar, Nabi bersabda, "Orang yang membunuh non-Muslim, maka dia tidak pernah merasakan aroma harumnya surga padahal aroma tersebut sudah bisa dirasakan dari jarak perjalanan empat puluh tahun". ${ }^{20}$

Penghormatan terhadap pemeluk agama lain juga dicontohkan dengan baik oleh 'Umar b. al-Khattâb ra. terhadap Uskup Severinus di hadapan kaum Nasrani dan kaum Muslimin di Baitul Maqdis Yerussalem ketika sedang berjalan-jalan ke gereja. Selanjutnya di depan gereja al-Qiyâmah (Anastasis) Uskup Severinus menyerahkan kunci kota Yerussalem kepada khalifah 'Umar. Ketika tiba waktu salat kemudian 'Umar minta diantarkan ke suatu tempat untuk menunaikan salat. Oleh Uskup Severinus beliau diantarkan ke dalam gereja, akan tetapi khalifah 'Umar menolak penghormatan tersebut sembari mengatakan bahwa dirinya khawatir hal itu akan menjadi dasar bagi kaum Muslimin generasi berikutnya untuk mengubah gereja-gereja menjadi masjid. Akhirnya Umar melaksanakan salatnya sendirian (munfarid) di luar atau di teras gereja tersebut.

Dari sini, menjadi menarik apabila mengacu kepada apa yang sudah termaktub dalam Piagam Madinah dari penetapan kewarganegaraan non-Muslim dalam dawlah islâmîyah serta berbagai teladan dari para sahabat merupakan kerangka baku dalam sistem dawlah islâmiyah. ${ }^{21}$ Apa yang kemudian direspons fuqabâ'-melalui ijtihadnya-yang bertentangan dengan hal itu tidak boleh diterima. Nașs-nașs al-Qur'ân dan Sunnah selain telah mengukuhkan prinsip ini

19 Abû Dâwud Sulaymân b. Ash'ath al-Sajastânî, Sunan Ab̂̀ Dâwud, Vol. 2 (Beirut: Dâr al-Kutub al-'Ilmîyah, 1996), 288.

20 Ibn Hajar al-'Asqalânî, Fatḥ al-Bârî bi Sharḥ Șậ̣̣̂ al-Bukhârî, Vol. 2 (Kairo: alMaktabah al-Salafiyah, 1986), 270.

21 Dawlah Islamîyah atau negara Islam adalah negara yang menjalankan aturan pemerintahannya berdasarkan prinsip hukum Islam, yang memberikan keamanan kepada segenap anggota masyarakatnya, baik Muslim atau kafir dhimmî. Lihat 'Abd al-Wahhâb Khallâf, al-Siyâsah al-Sharîyah (Kairo: Dâr al-Anșâr, 1977), 71. 
juga menerangkan hukum-hukum Islam yang berkenaan dengan interaksi non-Muslim di negara-negara Islam atas dasar berbuat baik dan bersikap adil. ${ }^{22}$

Oleh karenanya, tidak mengherankan jika seruan untuk mengkaji ulang konsep ahl al-dhimmah dalam konteks modern pun bermunculan. Muhammad Nazeer Kaka Khel menyatakan bahwa mayoritas negara Muslim saat ini adalah negara sekuler dan tidak memiliki model kerja yang dapat dijadikan dasar dalam mengkaji hak-hak non-Muslim di negara Islam. Oleh karenanya, dibutuhkan ijtihad baru untuk meletakkan hak-hak non-Muslim di negara Islam agar, sebagai agama, Islam bisa tetap berdiri di atas prinsip-prinsip toleransi, keadilan, dan kesetaraan. ${ }^{23}$

Fahmi Huwaidi pun menegaskan bahwa konsep klasik tentang dhimmî, meskipun bisa diterapkan pada zamannya dahulu, sudah tidak bisa lagi dipakai saat ini. Umat Islam tidak bisa menghindar dari kenyataan baru yang sama sekali berbeda di mana dasar "keanggotaan dalam sebuah negara" ditentukan bukan lagi oleh agama, tetapi oleh prinsip muwâtanah, atau nasionalitas. ${ }^{24}$

Kamran Hashemi juga menegaskan bahwa dengan kehadiran hukum hak asasi manusia internasional, maka tidak ada lagi definisi budaya, hak identitas dan hak terhadap budaya yang dibatasi hanya karena pemeluknya beragama minoritas. Oleh karenanya, penafsiran ulang terhadap konsep tradisional abl al-dhimmah mutlak dilakukan dalam kerangka harmonisasi umat beragama mayoritas dan minoritas dalam kehidupan bernegara. ${ }^{25}$

${ }^{22}$ Hal ini dapat dilihat pada firman Allah yang artinya: "Allah tidak melarang kamu untuk berbuat baik dan berlaku adil terhadap orang-orang yang tidak memerangimu karena agama dan tidak (pula) mengusirmu dari negerimu. Sesungguhnya Allah menyukai orang-orang yang berlaku adil. Sesunggguhnya Allah hanya melarang kamu menjadikan sebagai kawanmu orang-orang yang memerangi kamu karena agama dan mengusir kamu dari negerimu dan membantu (orang lain) untuk mengusirmu. Barangsiapa menjadikan mereka sebagai kawan, maka mereka itulah orang-orang yang zalim”. Lihat al-Qur'ân, 60: 8-9.

${ }^{23}$ Muhammad Nazeer Kaka Khel, "The Rights of non-Muslim in Islamic State", dalam http://www.qurtuba.edu.pk/thedialogue/The\%20Dialogue/1_2/5_Dr.\%20 M.\%20 Nazir.pdf.

${ }^{24}$ Fahmi Huwaidi, "The Concept of the Modern State and Its Manifestations in Contemporary Islamic Political Thought", http://alqudscenter.org/english/pages. php?local_type=128\&local_details (29 Desember 2011).

${ }^{25}$ Kamran Hashemi, "The Right of Minorities to Identity and the Chlenge of NonDiscrimination: A Study on the Effects of Traditional Muslim's Dhimmah on 
Abdullah Saeed juga menyatakan bahwa seiring dengan kebangkitan kembali Islam pada abad kedua puluh pemikiran revivalisme Islam mengenai ide kenegaraan banyak diadopsi oleh sejumlah pemikir Islam, meskipun rujukan tersebut justru menegasikan eksistensi negara bangsa. Dalam negara bangsa (nation state), konsep kenegaraan harus dibangun atas dasar pikir sekuler dengan tidak menempatkan satu kelompok agama mana pun untuk bisa mendominasi kelompok lain. Saeed kemudian mengungkapkan pemikiran Râshid al-Ghannûshî yang menyebutkan bahwa kaum ahl al-dhimmah berhak mendapatkan hak-hak antara lain kebebasan beriman termasuk kepada seorang Muslim yang ingin berpindah agama; memegang jabatan publik, perlakuan yang sama antara Muslim dan non-Muslim dalam hak dan kewajiban fiskal. Al-Ghannûshî menekankan bahwa titik tolak pandangannya ini didasarkan pada prinsip keadilan sebagai pilar hukum Islam. ${ }^{26}$

Abdullah an-Na'im juga berpandangan bahwa sharî‘ah tradisional meninggalkan ruang diskriminasi, khususnya terkait dengan hubungan antaragama (hak-hak non-Muslim). Berdasarkan alasan inilah, anNa'im berpendapat bahwa sharî́ah tradisional bila dihubungkan dengan pertanyaan diskriminasi terhadap hak-hak minoritas nonMuslim tidak lagi dapat dipertahankan. ${ }^{27}$

Nurcholish Madjid juga memaparkan bahwa dalam menganalisis QS. al-Tawbah [9]: 29 yang menjadi dasar konsep jizyah, konsep tradisional sharî‘ah harus menyertakan maksud dan konteks (asbâb alnu₹n̂i), dalam kasus ini perang Tabuk. Oleh karenanya, konsep jiąyah seharusnya hanya diaplikasikan pada masa peperangan, dan tidak dapat berlaku dalam konteks warga masyarakat damai sebagaimana yang terjadi saat ini. Lebih jauh dari itu, buku Fiqh Lintas Agama juga menegaskan bahwa jizyah bukan merupakan tradisi Islam, tetapi ia diadopsi oleh Islam. ${ }^{28}$

Current State Practices", International Journal on Minority and Group Rights (2006), 13, $1-25$.

${ }^{26}$ Abdullah Saeed, "Rethinking Citizenship Rights of non-Muslims in an Islamic State: Râshid al-Ghannûshi's Contribution to the Evolving Debate", Islam and Christian-Muslim Relations, Vol. 10, Issue 3 (1999), 307-323.

27 Abdullah Ahmed an-Naim, "Sharî‘ah dan Isu-isu HAM", dalam Charles Kurzman (ed.), Wacana Islam Liberal (Jakarta: Paramadina, 2001).

28 Nurcholish Madjid, et al., Fiqh Lintas Agama: Membangun Masyarakat Plural (Jakarta: Paramadina, 2004), 150-153. 
Penolakan sejumlah pemikir Muslim di atas terhadap eksistensi abl al-dhimmah di era modern berimplikasi pada wacana perubahan hak dan kewajiban warga negara non-Muslim di negara Islam modern. Artinya, dalam konteks kemodernan non-Muslim tidak lagi dapat diperlakukan sebagai abl al-dhimmah, sehingga ijtihad ulama tentang tidak diperbolehkannya non-Muslim menduduki posisi strategistermasuk presiden—di sebuah negara Muslim—sebagaimana posisi non-Muslim sebagai abl al-dhimmah pada masa kekhilafahan-patut ditinjau ulang.

\section{Kontroversi Seputar Ayat-ayat al-Qur'ân}

Kelompok yang menolak presiden non-Muslim, antara lain, mendasarkan pendapatnya pada QS. Âli 'Imrân [3]: 28 yang artinya: 'Janganlah orang-orang Mukmin mengambil orang-orang kafir menjadi pemimpin dengan meninggalkan orang-orang Mukmin. Barangsiapa berbuat demikian, niscaya lepaslah ia dari pertolongan Allah kecuali karena (siasat) memelihara diri dari sesuatu yang ditakuti dari mereka. Dan Allah memperingatkan kamu terhadap diri (siksa)Nya. Dan hanya kepada Allah kembali (mu)".

Di samping ayat 28 surah Âli 'Imrân, masih ada 11 ayat lagi yang sering digunakan untuk menolak presiden non-Muslim, yaitu; QS. alMâidah [5]: 51 dan 57, QS. al-Mumtaḥanah [60]: 1, QS. Âli 'Imrân [3]: 100 dan 118, QS. al-Mujâdilah [58]: 22, QS. al-Nisâ' [4]: 141 dan 144, QS. al-Anfâl [8]: 73, dan QS. al-Tawbah [9]: 8 dan71. Ayat-ayat yang disebutkan terakhir ini, meskipun memiliki redaksi yang berbeda satu sama lain, mengacu pada satu inti persoalan yang sama, yaitu umat Islam tidak diperkenankan memilih non-Muslim sebagai pemimpinnya, terutama menjadi presiden atau menjadi kepala negara komunitas Islam.

Dari beberapa ayat di atas, 5 ayat di antaranya berisi larangan untuk menjadikan orang-orang kafir sebagai pemimpin, di mana yang pertama, QS. Âli 'Imrân [3]: 28 meski melarang namun tetap memberi pengecualian dalam kondisi darurat, yaitu untuk memelibara diri dari sesuatu yang ditakuti dari mereka. Tentu saja dari teks ayat tersebut kita dapat menangkap nuansa konfrontatif yang menandakan ayat ini turun dalam kondisi peperangan, sehingga tentu saja tidak bisa sepenuhnya digunakan dalam kondisi damai, sebab al-Qur'ân juga memiliki ayat-ayat yang bernada kooperatif terhadap non-Muslim, di antaranya, sebagaimana firman Allah dalam QS. al-Mâidah [5]: 8 yang artinya: "Hai orang-orang yang beriman, hendaklah kamu jadi orang- 
orang yang selalu menegakkan (kebenaran) karena Allah, menjadi saksi dengan adil. Dan janganlah kebencianmu terhadap suatu kaum, mendorong kamu untuk berbuat tidak adil, berlaku adillah, karena adil itu lebih dekat kepada takwa, dan bertakwalah kepada Allah, sesungguhnya Allah mengetahui apa-apa yang kamu kerjakan”.

Kontradiksi antarayat al-Qur'ân inilah yang akhirnya melahirkan perbedaan pendapat di kalangan ulama dan pemikir Islam kontemporer. Perbedaan interpretasi para ulama mengenai ayat-ayat tersebut di atas serta perbedaan pandangan mengenai ayat manakah yang masih berlaku hingga saat ini atau yang manakah yang sudah dinaskh pada akhirnya melahirkan gagasan-gagasan dan pandangan yang bervariasi atau bahkan saling bertentangan.

\section{Ijtihad Baru atas Hak Non-Muslim}

Saat ini sangat perlu dipegang prinsip "setiap orang memiliki hak yang sama di depan hukum". Menolak prinsip ini berarti kita telah mendukung ketidakadilan. Padahal, ketidakadilan sesungguhnya merupakan musuh utama hukum Islam. Dengan mengutip Ibn Qayyim, Noryamin menyatakan, bukanlah sharî‘ah Islam jika wacana tafsir agama bersikap diskriminatif terhadap kelompok sosial tertentu. Jika pendapat ini diterima, maka menolak hak non-Muslim untuk menjadi presiden sama artinya dengan membuka fron permusuhan terhadap Islam yang mengajarkan keadilan dan kesetaraan. Bila tidak ingin diklaim sebagai para penentang Islam, maka segala bentuk hukum yang berwawasan diskriminatif, sekalipun diyakini banyak orang sebagai kebenaran, harus segera dianulir, atau minimal, perlu dikaji ulang. ${ }^{29}$

Pandangan fiqh klasik yang tidak membolehkan non-Muslim menjadi presiden di negara mayoritas Muslim, menurut Mahmoud Mohammad Thaha, tidak mampu memberikan nilai demokrasi yang proporsional kepada minoritas non-Muslim yang menjadi warga negara Islam modern dan atau sebuah negara yang diperintah oleh mayoritas Muslim. Karena itu, pandangan fiqh klasik yang bercorak diskriminatif terhadap non-Muslim, tegas Thaha, mendesak untuk segera direformasi. ${ }^{30}$

29 Noryamin Aini, "Dasar Legitimasi Sosiologis Gagasan Perubahan UndangUndang No. 1 Tahun 1974 dalam Konteks Perubahan Sosial”, Sharíab: Jurnal Ilmu Hukum, Vol. 7, No. 1 (Juni, 2007), 32-37.

${ }^{30}$ Syarif, Presiden non-Muslim, 140. 
Senada dengan Thaha, an-Naim menyatakan, pendapat umat Islam awal yang menolak presiden non-Muslim dapat dibenarkan. Argumentasinya karena sejak masa-masa pembentukan sharî‘ah (dan paling tidak untuk masa seribu tahun kemudian) belum ada konsepsi hak-hak asasi manusia universal di dunia ini. Sejak abad ke-7 hingga abad ke-20, kata an-Na'im, adalah suatu hal yang normal di seluruh dunia untuk menentukan status dan hak-hak seseorang berdasarkan agama. Dengan kata lain, boleh dikata, diskriminasi atas dasar agama adalah norma seluruh dunia pada waktu itu. ${ }^{31}$ Karena itu, pandangan fiqh klasik yang menolak presiden non-Muslim dapat dibenarkan oleh konteks historisnya. Akan tetapi, ini tidak dimaksudkan untuk menyatakan bahwa saat ini hal tersebut masih dapat dibenarkan. Mengingat pendapat yang menolak presiden non-Muslim itu dibenarkan oleh konteks historis yang ada di masa lalu, maka pembenaran itu, saat ini, dipandang telah selesai, sebab konteks historis yang ada sekarang ini sudah tentu berbeda dengan konteks historis yang ada di masa lalu. ${ }^{32}$ Setelah dikenal konsepsi hak-hak asasi universal, kata an-Na'im, diskriminasi atas dasar agama itu melanggar penegakan HAM. Kaum absolutis yang hidup di masa kontemporer, semisal al-Mawdûdî, Javid Iqbal, dan Ḥasan al-Turâbî, yang masih saja menolak presiden non-Muslim, adalah disebabkan karena mereka memandang aturan sharî́ah yang melarang umat Islam memilih presiden non-Muslim bersifat permanen. Padahal, sesungguhnya hal tersebut bersifat temporer. Bila saat ini pendapat yang menolak presiden non-Muslim masih tetap dipertahankan, maka tentu akan menimbulkan sesuatu yang kontra produktif karena selain dapat merusak citra umat dan agama Islam juga dapat menyulut timbulnya konflik dan perang, baik pada skala lokal maupun internasional. ${ }^{33}$

\section{Konteks Presiden Non-Muslim di Indonesia}

Menurut publikasi BPS pada bulan Agustus 2010, jumlah penduduk Indonesia adalah sebanyak 237.641 .326 orang, ${ }^{34}$ dan distribusi menurut agamanya, di tahun 2010, kira-kira 87,18\% dari penduduk Indonesia adalah pemeluk Islam, 6,9\% Protestan, 2,9\%

31 Abdullah Ahmad an-Na'im, Dekonstruksi Syariah, terj. Ahmad Suaedy dan Amiruddin Arrany (Yogyakarta: LKiS, 1994), 48 dan 88.

32 Ibid., 282.

${ }^{33}$ Ibid., 220.

34 "Laporan resmi Badan Pusat Statistika“", dalam http://www.bps.go.id/tab_sub/ view.php?kat=1\&tabel=1\&daftar=1\&id_subyek=12\&notab=1 (10 Oktober 2012). 
Katolik, 1,8\% Hindu, pemeluk agama Budha $0,72 \%$, pemeluk agama Konghucu 0,05\%. ${ }^{35}$ Artinya jumlah keseluruhan penduduk Muslim di Indonesia adalah sekitar 207,2 juta orang. Apabila dibandingkan dengan negara-negara berpenduduk mayoritas Muslim lainnya di dunia, maka angka ini merupakan angka penduduk Muslim terbesar di dunia.

Dalam konteks Indonesia diskursus seputar presiden non-Muslim merupakan isu yang sangat kontroversial dan sensitif. Untuk pertama kalinya pembahasan mengenai tema ini secara terbuka menurut Mujar Ibn Syarif dimulai di tahun 2006 pada seminar nasional yang diselenggarakan oleh Fakultas Syari'ah dan Hukum UIN Syarif Hidayatullah Jakarta yang dimotori oleh Badan Eksekutif Mahasiswa Fakultas Syari'ah bekerja sama dengan Forum Mahasiswa Syari'ah seIndonesia (FORMASI), BEM Fakultas Adab dan Humaniora, serta Partai Damai Sejahtera (PDS). Dalam seminar tersebut terjadi perdebatan sengit antara Fauzan al-Anshari (Juru Bicara Majelis Mujahidin Indonesia [MMI]) dengan Mujar Ibn Syarif (Pembantu Dekan I Fakultas Syari'ah UIN Syarif Hidayatullah Jakarta), Ismail Yusanto (Tokoh Hizbut Tahrir Indonesia (HTI), Ja'far Siddik, tokoh Front Pembela Islam (FPI)), Ruyandi Hutasoit (Ketua Umum PDS) dan Djohan Effendi (Ketua Indonesian Conference on Religion and Peace (ICRP).

Di antara narasumber dalam seminar tersebut yang paling keras menolak presiden non-Muslim adalah Ja'far Siddik dari FPI. Menurut Ja'far haram hukumnya non-Muslim menjadi presiden di Negara RI, mengingat Indonesia berpenduduk mayoritas Muslim terbesar di dunia. ${ }^{36}$ Berbeda dengan Ja'far, Djohan Effendi menyatakan, yang paling penting bagi suatu negera bukan apa bentuk negaranya atau siapa dan apa agama presidennya, melainkan yang terpenting adalah terwujudnya penegakan hukum dan keadilan, siapa pun presidennya. ${ }^{37}$

Menurut Syarif, setidaknya ada tiga alasan pokok yang mendasari kontroversi tentang presiden non-Muslim di Indonesia, yaitu pertama adalah karena UUD 1945 yang berlaku saat ini dijiwai Piagam Jakarta yang meniscayakan Presiden RI seorang yang beragama Islam. Alasan kedua, non-Muslim tidak dapat menjadi presiden RI, menurut Syarif

35 "Laporan resmi Badan Pusat Statistika“, dalam http://sp2010. bp.go.id/fies/ ebook/kewarganegaraan\%20penduduk\%20indonesia/files (10 Oktober 2012).

36 Ibid.

${ }^{37}$ Ibid. 
seperti dikutip dari Ibrahim Hosen karena Negara RI termasuk Negara Islam (Dâr al-Islâm), sebab mayoritas penduduk negara RI beragama Islam. Umat Islam pun dijamin dan dilindungi hak-haknya serta diberi kebebasan menjalankan agamanya. Pemerintah RI malah ikut menyebarluaskan, mengembangkan dan menyemarakkan syiar Islam. Bahkan mayoritas pejabat Negara RI mulai presiden, gubernur dan lain-lain adalah beragama Islam. ${ }^{38}$

Syarif, dengan mengutip Ibrahim Hosen, mengakui bahwa dalam Piagam Jakarta memang pernah ada persyaratan bahwa presiden RI harus beragama Islam dan orang Indonesia asli, namun persyaratan ini telah dicoret demi menjaga persatuan dan kesatuan bangsa yang saat itu memang diutamakan. Kendatipun begitu, tegas Hosen, bukan berarti faktor beragama Islam itu dapat diremehkan begitu saja, mengingat mayoritas penduduk Indonesia adalah Muslim. ${ }^{39}$

Argumentasi ketiga, non-Muslim dapat menjadi presiden RI yang berpenduduk mayoritas Muslim karena tidak benar di Indonesia ada konvensi yang diterima seluruh rakyat Indonesia bahwa presiden RI harus beragama Islam. Munculnya Ruyandi Hutasoit sebagai bakal calon presiden dari PDS menjelang pemilu presiden 2004 yang lalu, menurut Syarif cukup menjadi bukti kuat bahwa tidak benar di Indonesia berlaku konvensi yang diterima semua elemen bangsa bahwa presiden RI harus seorang Muslim. ${ }^{40}$

\section{Penutup}

Mengacu kepada ketentuan al-Qur'ân dan Sunnah yang berbicara soal kepemimpinan non-Muslim, mayoritas ulama masih tetap teguh berpendapat, dalam kondisi normal, kaum Muslimin di negara Islam, haram hukumnya memilih presiden non-Muslim. Akan tetapi, di saat darurat, seperti umat Islam yang sedang berada dalam ketertindasan politik, mereka dibolehkan memilih presiden non-Muslim. Hanya ada beberapa orang intelektual Muslim yang berpendapat sebaliknya, kaum Muslimin di negara Muslim boleh memilih presiden nonMuslim, kendatipun bukan dalam kondisi darurat. Sebab saat ini, menurut mereka, ketentuan al-Qur'ân dan Sunnah yang melarang umat Islam memilih presiden non-Muslim tidak berlaku lagi.

\footnotetext{
${ }^{38}$ Ibid., 196-197.

39 Ibid., 203.

${ }^{40}$ Ibid., 221.
} 


\section{Daftar Rujukan}

'Asqalânî (al), Ibn Hajar. Fatḥ al-Bârî bi Sharh Șaḅ̣̂̉ al-Bukhârî, Vol. 2. Kairo: al-Maktabah al-Salafìyah, 1986.

Aini, Noryamin. "Dasar Legitimasi Sosiologis: Gagasan Perubahan Undang-Undang No. 1 Tahun 1974 dalam Konteks Perubahan Sosial”, Shari'ab: Jurnal Ilmu Hukum, Vol. 7, No. 1, Juni, 2007.

Esposito, John L. Islam and Politics, terj. Joesoef Sou'yb. Jakarta: Bulan Bintang, 1990.

Ghazâlî (al), Abû Hâmid. al-Wajî̀, fî Fiqh al-Imâm al-Shâfîư̂, Vol. 2. Mesir: Muḥammad Muștafâ, 1318 H.

Hashemi, Kamran. "The Right of Minorities to Identity and the Chlenge of Non-Discrimination: A Study on the Effects of Traditional Muslim's Dhimmah on Current State Practices", International Journal on Minority and Group Rights, 2006.

http://sp2010.bp.go.id/fies/ebook/kewarganegaraan\%20penduduk $\% 20$ indonesia/files.

http:/ /www.bps.go.id/tab_sub/view.php?kat=1\&tabel=1\&daftar=1 \&id_subyek $=12 \&$ notab $=1$.

Huwaidi, Fahmi. "The Concept of the Modern State and Its Manifestations in Contemporary Islamic Political Thought", dalam http://alqudscenter.org/english/pages.php?local_type= 128\& local_details, 29 Desember 2011.

Kalabî (al), Muhammad b. Aḥmad b. al-Juza'i. al-Qawânûn al-Fiqhîyah fì Talkhîs al-Madhhab al-Mâlikîyah. Beirut: Dâr al-Qalam, t.th.

Kamil, Sukron. "The Progressive Shari'a Perspective of non-Muslim Rights", Kultur: The Indonesian Journal for Muslim Cultures, Vol. 4, No. 2, 2009.

Khallâf, 'Abd al-Wahhâb. al-Siyâsah al-Shar'ŷyah. Kairo: Dâr al-Anșâr, 1977.

Khel, Muhammad Nazeer Kaka. "The Rights of non-Muslim in Islamic State", dalam http://www.qurtuba.edu.pk/thedialogue/ The\%20Dialogue/1_2/5_Dr.\%20M.\%20Nazir.pdf.

Khiq, Farid Abdul. Fikih Politik Islam. Jakarta: Amzah, 2005.

Madjid, Nurcholish, et al. Fiqh Lintas Agama: Membangun Masyarakat Plural. Jakarta: Paramadina, 2004.

Madjid, Nurcholish. Cita-cita Politik Islam Era Reformasi. Jakarta: Paramadina, 1999. 
Moosa, Ibrahim. "The Dilemma of Islamic Rights Schemes", The Journal of Law and Religion (2000-2001), dalam http://duke. academia.edu/EbrahimMoosa/Papers/219897/The_Dilemma_of _Islamic_Rights_Schemes, 5 Desember 2011.

Na'im (an), Abdullah Ahmad. Dekonstruksi Syariah, terj. Ahmad Suaedy dan Amiruddin Arrany. Yogyakarta: LKiS, 1994.

-----. "Sharî́ah dan Isu-isu HAM", dalam Charles Kurzman (ed.), Wacana Islam Liberal. Jakarta: Paramadina, 2001.

Ploch, Lauren. "Nigeria Elections and Issues for Congress", Congressional Research Service, May 17th 2011, dalam http://alpha.digital.library.unt.edu/ark:/67531/metadc40225/m1 /1/high_res_d/RL33964_2011May17.pdf, 28 Mei 2012.

Qaradhawi (al), Yusuf. Fiqih Jibad: Sebuah Karya Monumental Terlengkap tentang Jihad menurut Al-Qur'an dan Sunnah, terj. Irfan Maulana Hakim. Bandung: Mizan, 2010.

Ramadhan, Tariq. Radical Reform: Islamic Ethics and Liberation. Oxford: Oxford University Press, 2009.

Saeed, Abdullah. "Rethinking Citizenship Rights of non-Muslims in an Islamic State: Râshid al-Ghannûshi's Contribution to the Evolving Debate", Islam and Christian-Muslim Relations, Vol. 10, Issue 3, 1999.

Sajastânî (al), Abû Dâwud Sulaymân b. Ash'ath. Sunan Abî Dâwud, Vol. 2. Beirut: Dâr al-Kutub al-'Ilmîyah, 1996.

Suyûṭ̂ (al), 'Abd al-Raḥmân b. Abû Bakr. al-Jâmi' al-Ṣaghîr fi Hadîth alBashîr al-Nadhîr. t.t.: t.tp., t.th.

Syarif, Mujar Ibnu. Presiden non-Muslim di Negara Muslim: Tinjauan dari Perspektif Politik Islam dan Relevansinya dalam Konteks Indonesia. Jakarta: Pustaka Sinar Harapan, 2006.

'Uthaymîn (al), Shaykh Muhammad b. Șâliḥ. Huqûq Dâ'at ilayhâ alFitrah wa Qarrarahâ al-Sharíah. t.t.: Madâr al-Wațan, 1427 H.

Watt, W. Montgomery. Islamic Political Thought. Edinburgh: Edinburgh University Press, 2003. 